\title{
SPRAWOZDANIE Z MIĘDZYNARODOWEJ KONFERENCJI PT. MOTYW CHOROBY W HISTORII LITERATURY I KULTURY POSTTOTALITARNYCH PAŃSTW EUROPY ŚRODKOWO-WSCHODNIEJ
}

\author{
Marta Kaczmarczyk \\ Katedra Literatury Rosyjskiej, Ukraińskiej i Białoruskiej KUL
}

6 listopada 2020 roku odbyła się zdalna jednodniowa Międzynarodowa konferencja naukowa pt. Motyw choroby w historii literatury $i$ kultury posttotalitarnych państw Europy Środkowo-Wschodniej. Konferencja została zorganizowana z inicjatywy uczonych reprezentujących Pracownię Badań nad Ukraińską Tożsamością oraz Katedrę Ukrainistyki Uniwersytetu Warszawskiego. Zaproponowany temat konferencji odwołujący się do refleksji nad obecnością choroby w literaturze i kulturze spotkał się z zainteresowaniem badaczy z polskich i zagranicznych ośrodków naukowych, którzy zaprezentowali podczas konferencji szeroki wachlarz możliwości i potencjału dyskursu chorobowego, który w ostatnich latach przeżywa rodzaj ,zwrotu maladycznego" (M. Ładoń).

Po uroczystym rozpoczęciu konferencji moderatorki pierwszej sekcji-Zinajida Kosytska i Katarzyna Jakubowska-Krawczyk - oddały głos dr Iwonie Boruszkowskiej, która w obszernym i interesującym wykładzie przedstawiła perspektywy badawcze ciągle rozwijających się studiów nad chorobą. Autorka cieszącej się uznaniem monografii pt. Sygnatury choroby. Literatura defektu w ukraińskim modernizmie (Warszawa 2018) zwróciła uwagę na polskie propozycje badawcze, $\mathrm{m}$.in. na studium poświęcone omówieniu doświadczenia utraty zdrowia Małgorzaty Okupnik (M. Okupnik, $W$ niewoli ciała. Doświadczenie utraty zdrowia i jego reprezentacje, Kraków 1018), jak również na opublikowaną w 2019 roku monografię Moniki Ładoń pt. Choroba jako literatura. Studia maladyczne (Katowice 2019), akcentując szeroką perspektywę dla rozwoju studiów nad chorobą. Następnie głos zabrała prof. Agnieszka Matusiak, która zaprezentowała referat poświęcony kwestii mierzenia się z zagadnieniem traumy pt. Trauma utraty. „,Może Estera” Katii Petrovskiej. Wrocławska slawistka zaznaczyła, że prezentowany materiał stanowi fragment jej najnowszej publikacji zatytułowanej Wyjść z milczenia. Dekolonialne zmagania kultury i literatury ukraińskiej XXI wieku z trauma posttotalitarna 
(Wojnowice-Wrocław 2020), a wykorzystana do analizy zjawiska powieść Katii Petrowskiej stanowi udaną dekolonialną próbę zmiany ustalonej narracji dotyczącej stosunków ukraińsko-żydowskich. Jest to jednocześnie, co również podkreślała Matusiak, jeden z nielicznych we współczesnej literaturze ukraińskiej utworów, które omawiają tę bolesną i niewyjaśnioną kwestię dotyczącą udziału i odpowiedzialności Ukraińców w Holokauście. Profesor UW Walentyna Sobol zaprezentowała referat zatytułowany Мотив чудесного зиілення в літературі бароко. Badaczka prześledziła obecność i funkcjonowanie motywu cudownego uzdrowienia na podstawie wybranych tekstów literatury barokowej. Tereza Lewczuk (Łuck, Ukraina) swoje rozważania nad chorobą umiejscowiła w kręgu literatury modernistycznej, zwracając uwagę na psychopatyczny charakter literatury modernistycznej, podkreślając tym samym dość aktywne wykorzystanie przez twórców modernizmu motywu szaleństwa (Психопатичний компонент модерністської літератури). Również w kręgu literatury modernistycznej umieszone było wystąpienie Marty Kaczmarczyk. Badaczka lubelska przedstawiła refleksję poświęconą narracji chorobowej obecnej w literaturze dokumentu osobistego Łesi Ukrainki, zwracając uwagę na somatyczne ślady chorowania utrwalone w listach ukraińskiej pisarki przełomu XIX i XX wieku. Ostatnie wystąpienie w pierwszym panelu konferencji poświęcone było analizie motywu choroby na podstawie powieści Jeleny Czyżowej Czas kobiet. Autorka referatu - dr hab. Monika Zielińska (UW) podzieliła się z uczestnikami refleksją nie tylko nad chorobą cielesną - jednym z motywów obecnych $\mathrm{w}$ wybranej powieści, zauważyła również chorobowy i destrukcyjny wpływ systemu komunistycznego na jednostkę, będący źródłem cierpień, chorób i śmierci (Motyw choroby w powieści Jeleny Czyżowej „,Czas kobiet”).

Podsumowaniem tej części konferencji była interesująca dyskusja, w której po raz kolejny wybrzmiały głosy podkreślające duży potencjał studiów poświęconych chorobie, w ramach których prowadzone są analizy szeroko rozumianej patografii.

Po przerwie obrady rozpoczęły się od wystąpienia Oksany Wysznewskiej (Łuck, Ukraina). Badaczka ukraińska omówiła motyw ślepoty i cudownego odzyskania wzroku w kontekście chrześcijańskim, analizując i porównując ich funkcjonowanie w Powieści lat minionych i Kronikach Galla Anonima (Християнський контекст мотиву сліпоти-прозріння в «Повісті минулих літ» і польських хроніках). Polemice pomiędzy Piotrem Mohyłą a Kasjanem Sakowiczem poświęcone było wystąpienie Mariji Jankowej (Kijów, Ukraina). Utrwalona na stronach Litosu dyskusja stała się przyczynkiem do rozważań nad XVII-wiecznym sposobem postrzegania ułomności czy kalectwa. Defekt fizyczny Sakowicza - brak ucha stał się przyczynkiem do obecnych w dyskusji przytyków o nieprzypadkowości kalectwa i wyprowadzanej z niego boskiej kary. Jednocześnie badaczka podkreśliła, że tego rodzaju uszczypliwa narracja 
stanowiła typowy na ów czas sposób dyskutowania. Slawista ukraiński Feliks Sztejnbuk reprezentujący ośrodek badawczy z Bratysławy przedstawił analizę powieści Ołesia Ulianenka Siedoj. Autor wielu publikacji poświęconych twórczości Ulianenki podkreślił, że twórczość tego ukraińskiego pisarza wciąż jeszcze domaga się recepcji, czemu naprzeciw wychodzą jego badania, będące alternatywą dla tradycyjnego odczytania odczytania twórczości tego pisarza (Хворобливий сон Іванди у повісті Олеся Ульяненка «Сєдой»). Kijowska badaczka Hałyna Żukowska zaproponowała refleksję nad wykorzystaniem obrazu wiedźmy przez pisarkę ukraińską Oksanę Zabużko. Uczona przeanalizowała utwór Kazka pro kałynowu sopiłku, zwracając uwagę na koncepcję obrazu wiedźmy, która w traktowaniu Zabużko uzyskuje tak pozytywny, jak i negatywny obraz (Семантичне поле відьомства в сучасній украӥнській літературі (на матеріалі «Казки про калинову сопілку» Оксани Забуюкко). Motywom choroby i ich literackim realizacjom poświęcone zostały również dwa kolejne wystąpienia autorstwa Oksany Terebus «Не треба боятися хвороб - вони гартують тіло $і$ душу» (за книгою житейських $i$ духовних настанов Мирослава Дочиния «Многії літа. Благії літаі») i Wiktorii Sokołowej Художня функиійність фізичних дефектів у творчості Кнута Гамсуна.

$\mathrm{W}$ trakcie popołudniowej sekcji wybrzmiały referaty wychodzące poza ramy badań literaturoznawczych, również nawiązujące do dyskursu maladycznego, który przecież plasuje się na przecięciu różnych metodologii i inspiracji badawczych (w tym językoznawczych, kulturoznawczych, filozoficznych i in.). Kijowska artystka Zinajida Kosytska zaprezentowała prace plastyczne wykonywane metodą wycinania bądź wyrywania, wykonane czy wykonywane przez osoby chore czy zmagające się z chorobą, ujmując taką formę działalności artystycznej jako formę terapii, pomagającą zmagać się z chorobą (Мистецтво витинання як творчість і як арт-терапія (на матеріалах Украӥни середини XX - початку XXI cm.)). W bezpośredniej bliskości do wyżej wymienionego tematu rozważań pozostawało wystąpienie Michała Szymki, który podzielił się refleksją dotyczącą obecności choroby we współczesnej ukraińskiej sztuce kobiecej, wyróżniając trzy postacie choroby: duchową, cielesną i społeczną, których odzwierciedlenie odnajdujemy we współczesnej sztuce ukraińskiej autorstwa kobiet (Motyw choroby w ukraińskiej sztuce kobiecej). Również w sferze sztuki pozostawało wystąpienie Katarzyny Jakubowskiej-Krawczyk, która zaprezentowała obecne we współczesnej ukraińskiej sztuce sakralnej motywy ciała - ciała chorego i ciała martwego (Ciało chore - ciało martwe we współczesnej ukrainskiej sztuce sakralnej). Oksana Borys zaprezentowała językoznawcze aspekty dyskursu maladycznego, prezentując analizę eponimów - terminów medycznych, określających nazwy schorzeń i chorób, w których członie obecne są nazwy własne, np. zespół Aspergera itp. (Хвороба з людським обличчям або про епоніми у медичній термінологіï). 
Ostatnie trzy wystąienia osadzone były ponownie w dyskursie literaturoznawczym. Halyna Jastrubecka omówiła zagadnienie psychofizjologii twórcy i jej wpływu na styl pisarza (Психофізіологія мития в диспозииіï до стилю), natomiast referaty Pauliny Olechowskiej i Marty Zambrzyckiej dotyczyły analizy najnowszej literatury ukraińskiej. Zajmująca się badaniem współczesnej ukraińskiej prozy kobiecej Paulina Olechowska zaprezentowała analizę opowiadania Tani Malarczuk Bies głodu, zwracając uwagę na kwestię wciąż nieprzepracowanej traumy Wielkiego Głodu na Ukrainie, jak również na obecną w utworze narrację świadomości procesu, jako rodzaj narracji maladycznej, rejestrującej stan choroby tożsamości. Marta Zambrzycka zaprezentowała narracje chorobowe obecne w tzw. literaturze popularnej jako swego rodzaju projekt społeczny, mający na celu uwrażliwianie czytelników i odbiorców na obecność chorego-innego. Dla prezentacji problemu badaczka wykorzystała trzy pozycje: książkę Marka Livina Riki i drogi, która, nota bene, ukazała się w 2020 roku w polskim przekładzie, odwołującą się do problemu chorych na zespół Aspergera, książkę Switłany Taran Koły ty porucz - mierzącą się z kwestią choroby AIDS oraz projekt multimedialny Janiny Sokołowej Ja, Nina - fabularyzowaną autobiografię chorej na nowotwór autorki - popularnej ukraińskiej dziennikarki, prezenterki telewizyjnej, aktorki i działaczki społecznej. 